HUMORS, HORMONES AND THE MIND 


\section{Humors, Hormones and the Mind}

An Approach to the Understanding of
Behaviour

\section{Bernard T. Donovan}

Department of Physiology

Institute of Psychiatry

De Crespigny Park, London SE5 8AF 
All rights reserved. No reproduction, copy or transmission of this publication may be made without written permission.

No paragraph of this publication may be reproduced, copied or transmitted save with written permission or in accordance with the provisions of the Copyright Act 1956 (as amended), or under the terms of any licence permitting limited copying issued by the Copyright Licensing Agency, 33 - 4 Alfred Place, London WC1E 7DP.

Any person who does any unauthorised act in relation to this publication may be liable to criminal prosecution and civil claims for damages.

First published 1988

Published by

THE MACMILLAN PRESS LTD

Houndmills, Basingstoke, Hampshire RG21 2XS

and London

Companies and representatives

throughout the world

Typesetting by Communitype, Leicester

British Library Cataloguing in Publication Data

Donovan, Bernard T.

Humors, hormones and the mind : an approach to the understanding of behaviour.

$\begin{array}{ll}\text { 1. Human behavior } 2 \text {. Hormones } & \end{array}$

I. Title

$612^{\prime} .405$

BF121

ISBN 978-0-333-45293-6 ISBN 978-1-349-19025-6 (eBook)

DOI 10.1007/978-1-349-19025-6

Published in the United States and Canada by Stockton Press

15 East 26th Street, New York, NY 10010

Library of Congress Cataloging-in-Publication Data

Donovan, Bernard T.

Humors, hormones and the mind : an approach to the understanding of behaviour / Bernard T. Donovan.

p.

Includes index.

$\mathrm{cm}$.

ISBN 978-0-935859-32-4 (Stockton Press) : $\$ 60.00$

1. Psychoneuroendocrinology. I. Title.

[DNLM: 1. Behavior-physiology. 2. Brain-physiology.

3. Hormones-physiology. 4. Psychophysiology. WK 102 D743hal QP356.45.D66 1987

$612^{\prime} .814-\mathrm{dc} 19$ 


\section{Contents}

Preface vii

Part 1 Introduction

1 Humours, Humors and Hormones 3

2 The Neural Basis of Humoral Action 23

Part 2 Humors

3 Neurohumors 41

4 Hormonal Humors 64

5 The Master Humors $\quad 85$

6 Peptide Humors 112

7 Immunohumors 138

Part 3 How the Humors Affect the Mind

8 Senses 149

9 Emotion 158

10 Stress 172

11 Aggression 185

12 Learning and Memory 198

13 Eating and Drinking 211

14 Masculinity 232

15 Femininity 257

16 Intellect and Personality 271

$\begin{array}{ll}\text { Index } & 282\end{array}$ 


\section{Preface}

Brain science is passing though a revolution, with the progress in recent years being little short of astounding. A major force in the upheaval has been, and still is, the contribution of research on hormones and humors; for the old idea that the brain served as conductor of a hormonal orchestra, with a major gland attached to the base of the brain, the pituitary gland, acting as the controlling baton, has given way to a much more dynamic concept, for the brain itself produces many hormonal factors. Almost every bodily function is affected by hormones, from eating, drinking, digestion, emotion, learning, memory, and intellectual endeavour, to muscular action, growth and sexual activity, but coverage in the present work is largely restricted to the chemical control of behaviour, for it is here that progress is of greatest import. The new knowledge is not simply of theoretical significance, but of major practical impact, for in addition to helping us understand ourselves, and the way we behave, it is providing novel tools for the treatment of mental illness, and altering the approach of psychiatrists and psychologists to their patients, as well as that of the social services to their clients.

Inevitably, much of the new information appears a little complicated and difficult to comprehend, but its impact upon society and the way we live is such as to merit the present attempt to convey some of the interest and excitement in a non-technical but systematic manner. Both the layman and the professional will find much of interest within these pages, and the material can be approached in several ways. The knowledgeable might prefer to start at the beginning and continue to the end; the tyro may opt to dip into a chapter on some particular aspect of behaviour and explore from there. It is for this reason that numerous cross-references have been inserted. Whatever the approach, the reader is certain to encounter material of immediate appeal. The fact that the subject matter is of direct concern to the drug-taker, endocrinologist, immunologist, nutritionist, physiologist, psychologist, psychiatrist, and teacher, to name but a few, should not be a deterrent: it is of great moment to us all.

This book develops a point of view presented in a more technical way, primarily for psychiatrists, in my Hormones and Human Behaviour (published in 1985). Some matters touched upon lightly here are covered in 
greater depth in that work and to a degree the volumes are complementary. But each stands alone.

Readers should note that in places I have deliberately reproduced quotations from other sources exactly as they originally appeared. This has occasionally led to oddities of grammar, punctuation and spelling.

London, 1987

B.T.D. 